\title{
The ONE Study compares cell therapy products in organ transplantation: introduction to a review series on suppressive monocyte-derived cells
}

\author{
Edward K Geissler
}

\section{The problem}

Organ transplantation has evolved into a reliable lifesaving procedure where good organ function is quickly restored by the transplant and, typically, the patient can return to an active lifestyle. Unfortunately, the human immune system reacts strongly against allogeneic tissues, and will destroy a transplanted organ within days or weeks after transplantation if the immune system is not depleted or inhibited by immunosuppressive drugs. Near elimination of the immune system through non-specific [1] or specific depletive therapies [2] prior to transplantation is one strategy that is effective at preventing early reactions to the graft, and in a few cases in establishing tolerance-promoting chimerism [3,4]. But these treatments are harsh with significant side effects, and donor tolerance is not assured after the immune system recovers. Thus, the current standard of care for transplant recipients involves the use of general immunosuppressive drugs that reduce graft destruction. The downside of their use is that the whole immune system is impaired, often causing a myriad of side-effects (for example, toxicity, infection, and malignancy), and chronic rejection remains a long-term problem. The lack of improvement in 10-year organ survival rates over the past decades for renal [5] and liver [6] transplantation highlight the need for new therapeutic approaches to prevent organ destruction.

\section{Cell therapy: The ONE Study focus}

The ONE Study is the acronym for a large scale collaborative project funded by the European Community's FP7 [7]. The project is entitled: "A Unified Approach to Evaluating Cellular Immunotherapy in Solid Organ

\footnotetext{
* Correspondence: Edward.Geissler@klinik.uni-regensburg.de
Department of Surgery, University Hospital Regensburg, University of
Regensburg, Regensburg, Franz-Josef-Strauss-Allee 11,93053, Regensburg,

* Correspondence: Edward.Geissler@klinik.uni-regensburg.de
Department of Surgery, University Hospital Regensburg, University of
Regensburg, Regensburg, Franz-Josef-Strauss-Allee 11, 93053, Regensbu

* Correspondence: Edward.Geissler@klinik.uni-regensburg.de
Department of Surgery, University Hospital Regensburg, University of
Regensburg, Regensburg, Franz-Josef-Strauss-Allee 11, 93053, Regensburg, Germany
}

Transplantation" and involves scientists from Germany, France, Italy, the United Kingdom and the United States with the aim of improving treatment and the overall quality of life for kidney transplant patients through cell therapy. The goal of the project is to develop and test an array of novel manufactured cell therapy products that have promise to reduce a transplant patient's life-long dependency on immunosuppressive drugs. In principle, the hypothesis behind cell therapy in the context of organ transplantation is that treating recipients with a concentrated dose of well-defined regulatory immune cells near the time of transplantation will trigger a selfsustaining immune regulation that establishes a level of functional protection against allograft destruction. This concept is fundamentally different from other modes of treatment for transplant recipients since the therapy supplements, or 'adds-in', a functional cellular component of the immune system that is believed capable of precipitating and establishing a protective immunological balance favoring allograft survival. In contrast, all other current forms of therapy seek to take away immune function through depletion of classes of detrimental immune cells, or through blockage of signals in these cells required for immune reactions; this form of 'functionally inhibitory' therapy primarily causes a general suppression of the immune system.

The ONE Study consortium explores the feasibility and potential of cell therapy in organ transplantation by bringing together experts to test different regulatory cell products composed of specific $\mathrm{T}$ cell ( $\mathrm{T}$ regulatory cell, Treg and $\mathrm{T}$ regulatory type 1 cell, Tr 1 cell), dendritic cell and macrophage subpopulations. While the primary objective of the study is to perform a stringent side-byside comparison of these cell products using a single (ONE) standardized trial protocol, a secondary aim is to use this unique cooperative opportunity to experimentally examine the immunoregulatory characteristics of the cell products to be tested. 


\section{Monocyte-derived regulatory cell populations}

To address the issue of comparing and contrasting suppressive cell populations with cell therapy potential, a series of investigative workshops have been planned within the context of The ONE Study. The first of these workshops has already taken place this year with an emphasis exclusively on producing and comparing suppressive populations of cells derived from monocytes, namely tolerogenic dendritic cells (tol DCs) [8], myeloid-derived suppressor cells (MDSCs) [9], IL-10induced DCs (DC-10 cells) [10] and regulatory macrophages ( $M$ regs) $[11,12]$. A central premise of this workshop is that each cell type is produced side-by-side in a single laboratory from the same leucapheresis products, thus eliminating differences attributable to cell sources and inter-laboratory conditions. This type of collaborative effort is only possible through a large-scale integrating grant such as The ONE Study. While the final results of this first workshop are still pending, the assembled group of workshop participants decided it would be informative to perform a separate review of each of the monocyte-derived regulatory cell populations under investigation.

In the current issue of Transplantation Research, workshop participants present literature and their perspectives on the specific cell population that they produced for comparison. It is important to keep in mind that the workshop investigators are studying the different monocyte-derived regulatory cells more from a cell production standpoint, versus taking a view towards normal physiological development. Indeed, the in vivo temporal and complex signals directing a blood monocyte or tissue macrophage to become activated, to take on professional antigen-presenting functions, to migrate to lymphoid structures, or to become suppressive, are not fully understood. However, the workshop participants primarily aim to distinguish or show similarities between suppressive monocyte-derived cell populations that can be generated under defined in vitro conditions. This is an important undertaking since cell therapy applications demand an ex vivo cultivation phase to manufacture a homogenous and reproducible cell product.

For comparison, six cell populations were derived from blood monocytes by investigators of the workshop group: (1) tol DCs, (2) DC-10 cells, (3) rapamycinconditioned DCs (rapa DCs), (4) MDSCs, (5) M regs and (6) monocytes conditioned with mesenchymal stem cells (MSCs). The variety of stimuli that are considered for cell production is especially evident with tol DCs. The workshop group concentrated on tol DCs generated under conditions including stimulation with low concentrations of GM-CSF [13], and with combinations of GMCSF, IL-4 and IL-10 (DC-10 cells [14]) or rapamycin (rapa DCs [15]). Besides comparing the characteristics (gene expression, phenotype, function, etc.) of these closely related cells to each other, they are comparable to cells such as MDSCs, which can be generated under similar conditions, but in the presence of prostaglandin $\mathrm{E}_{2}$ [16] or other stimuli. Interestingly, to further show the potential overlapping properties of monocytederived suppressive cells, recent evidence suggests that MSCs mediate their immunosuppressive effect through induction of an auxiliary macrophage via IL-10 or prostaglandin $E_{2}$ [17]; whether these conditioned macrophages are unique or similar to other suppressive macrophages is a question to be addressed through the workshop. Finally, our own group in Regensburg has been actively studying the suppressive properties of monocyte-derived cells generated through M-CSFinduced maturation in combination with late ex vivo interferon gamma stimulation ( $M$ regs [18]). While $M$ regs have a distinct phenotype compared to other known suppressive macrophages [12], and have already been used in a limited number of transplant recipients [11], it remains unclear how these cells compare phenotypically and functionally to ex vivo generated tol DCs or MDSCs; The ONE Study workshop also seeks to answer this question.

In preparing to assess the results of the first $O N E$ Study workshop on monocyte-derived suppressor cells, the involved investigators deemed it useful to review the present literature on tolerogenic DCs and macrophage/ myeloid derived suppressor cell populations. The authors of the reviews consider the similarities and differences of these closely related cell populations, and suggest how they may best be applied as a cell therapy meant to reduce organ transplant rejection. Indeed, cell therapy is entering a critical early phase of testing in transplantation, mandating that we take the necessary steps to determine which cell populations are most adaptable and effective for this purpose. The reviews in this issue of Transplantation Research offer a view into the future of cell therapy involving suppressive cells derived from readily available circulating monocytes.

Received: 30 August 2012 Accepted: 31 August 2012

Published: 28 September 2012

\section{References}

1. Cosimi $A B$, Sachs $D H$ : Mixed chimerism and transplantation tolerance. Transplantation 2004, 77:943-946.

2. Barth RN, Janus CA, Lillesand CA, Radke NA, Pirsch JD, Becker BN, Fernandez LA, Chin LT, Becker YT, Odorico JS, D'Alessandro AM, Sollinger HW, Knechtle $\mathrm{SJ}$ : Outcomes at 3 years of a prospective pilot study of Campath-1 $\mathrm{H}$ and sirolimus immunosuppression for renal transplantation. Transpl Int 2006, 19:885-892.

3. Kawai T, Cosimi AB, Spitzer TR, Tolkoff-Rubin N, Suthanthiran M, Saidman SL, Shaffer J, Preffer Fl, Ding R, Sharma V, Fishman JA, Dey B, Ko DS, Hertl M, Goes NB, Wong W, Williams WW Jr, Colvin RB, Sykes M, Sachs DH: HLA-mismatched renal transplantation without maintenance immunosuppression. N Engl J Med 2008, 358:353-361. 
4. Leventhal J, Abecassis M, Miller J, Gallon L, Ravindra K, Tollerud DJ, King B, Elliott MJ, Herzig G, Herzig R, Ildstad ST: Chimerism and tolerance without GVHD or engraftment syndrome in HLA-mismatched combined kidney and hematopoietic stem cell transplantation. Sci Transl Med 2012, 4:124ra28.

5. Meier-Kriesche HU, Schold JD, Kaplan B: Long-term renal allograft survival: have we made significant progress or is it time to rethink our analytic and therapeutic strategies? Am J Transplant 2004, 4:1289-1295.

6. Gelson W, Hoare M, Dawwas MF, Vowler S, Gibbs P, Alexander G: The pattern of late mortality in liver transplant recipients in the United Kingdom. Transplantation 2011, 91:1240-1244.

7. EU FP7 Collaborative Project: A unified approach to evaluating cellular immunotherapy in solid organ transplantation. www.onestudy.org.

8. Morelli AE, Thomson AW: Tolerogenic dendritic cells and the quest for transplant tolerance. Nat Rev Immunol 2007, 7:610-621.

9. Obermajer N, Muthuswamy R, Lesnock J, Edwards RP, Kalinski P: Positive feedback between $\mathrm{PGE}_{2}$ and $\mathrm{COX} 2$ redirects the differentiation of human dendritic cells toward stable myeloid-derived suppressor cells. Blood 2011, 118:5498-5505.

10. Gregori S, Tomasoni D, Pacciani V, Scirpoli M, Battaglia M, Magnani CF, Hauben E, Roncarolo MG: Differentiation of type $1 \mathrm{~T}$ regulatory cells (Tr1) by tolerogenic DC-10 requires the IL-10-dependent ILT4/HLA-G pathway. Blood 2010, 116:935-944.

11. Hutchinson JA, Riquelme P, Sawitzki B, Tomiuk S, Miqueu P, Zuhayra M, Oberg HH, Pascher A, Lützen U, Janssen U, Broichhausen C, Renders L, Thaiss F, Scheuermann E, Henze E, Volk HD, Chatenoud L, Lechler R, Wood KJ, Kabelitz D, Schlitt HJ, Geissler EK, Fändrich F: Cutting edge: Immunological consequences and trafficking of human regulatory macrophages administered to renal transplant recipients. J Immunol 2011, 187:2072-2078.

12. Riquelme P, Tomiuk S, Kammler A, Fändrich F, Schlitt HJ, Geissler EK, Hutchinson JA: IFN-g-induced iNOS expression in mouse regulatory macrophages prolongs allograft survival in fully immunocompetent recipients. Mol Ther 2012, doi:10.1038/mt.2012.168.

13. Moreau A: The ONE Study Workshop. Transplantation Res 2012, publication details pending.

14. Amodo G: The ONE Study Workshop. Transplantation Res 2012, publication details pending.

15. Macedo C: The ONE Study Workshop. Transplantation Res 2012, publication details pending.

16. Obermajer N: The ONE Study Workshop. Transplantation Res 2012, publication details pending.

17. Eggenhofer E: The ONE Study Workshop. Transplantation Res 2012, publication details pending.

18. Riquelme P: The ONE Study Workshop. Transplantation Res 2012, publication details pending.

\section{Submit your next manuscript to BioMed Central and take full advantage of:}

- Convenient online submission

- Thorough peer review

- No space constraints or color figure charges

- Immediate publication on acceptance

- Inclusion in PubMed, CAS, Scopus and Google Scholar

- Research which is freely available for redistribution

Submit your manuscript at www.biomedcentral.com/submit
C Biomed Central 